\title{
Sistem Informasi Tracer Study Alumni Universitas Negeri Semarang Dengan Aplikasi Digital Maps
}

\author{
Zulfikar Adi Nugroho ${ }^{1}$, Riza Arifudin ${ }^{2}$ \\ ${ }^{1,2}$ Jurusan Matematika, FMIPA Unnes, Semarang \\ Email: ${ }^{1}$ zulfikaradi10@ gmail.com, ${ }^{2}$ rizaarifudin@ gmail.com
}

\begin{abstract}
Abstrak
Tracer study alumni merupakan salah satu metode yang digunakan untuk menelusuri informasi mengenai alumni. Informasi yang diambil meliputi identitas pribadi alumni, riwayat pendidikan di Universitas Negeri Semarang, riwayat pekerjaan, serta masukan yang diberikan kepada Universitas Negeri Semarang. Salah satu data yang sulit untuk diperoleh adalah data valid mengenai alamat pekerjaan alumni serta cara menyajikan data alamat pekerjaan alumni. Digital Maps adalah representasi fenomena geografik yang disimpan untuk ditampilkan dan dianalisis oleh komputer. Setiap objek pada peta digital disimpan sebagai sebuah atau sekumpulan koordinat. Posisi tempat kerja atau posisi kantor merupakan salah satu data geografis berupa titik, sedangkan titik dalam data geografi merupakan bagian dari sebuah peta. Sehingga titik yang baik adalah titik yang dapat diproyeksikan kedalam sebuah peta. Dalam tulisan ini, akan dibahas rancang bangun sistem informasi Tracer Study alumni Universitas Negeri Semarang dengan aplikasi Digital Maps.
\end{abstract}

Kata kunci: Tracer Study, Digital Maps

\section{PENDAHULUAN}

Alumni perguruan tinggi merupakan komponen yang seharusnya saling memiliki sinergi baik. Eksistensi alumni ini sangat perlu untuk diketahui agar institusi mampu melakukan refleksi demi tercapainya perbaikan kualitas pembelajaran dan segala kegiatan akademik. Masukan dari alumni dinilai penting karena merupakan bagian yang tidak terpisahkan dengan lembaga. Untuk mendapatkan informasi tersebut dilaksanakan sebuah kegiatan survey alumni yang dinamakan kegiatan Tracer Study Alumni yang disingkat TSA.

Menurut [1,2] kegiatan yang dilakukan oleh tim TSA adalah melakukan survey untuk mendapatkan informasi dari alumni dengan menggunakan sistem Questionnaire online, informasi yang diperoleh dari Questionnaire online adalah seputar karakteristik dan sosiologi sebelum kuliah, kegiatan pendidikan dan pembelajaran di kampus, transisi kedunia kerja, pekerjaan dan kompetensi hubungan pekerjaan dengan program studi. Setelah informasi atau data diperoleh, selanjutnya data akan diolah oleh tim olah data.

Kegiatan pengolahan data TSA masih dilakukan dengan menggunakan metode manual yang membutuhkan waktu lama. Data yang diperoleh juga sering kali mengalami kesulitan untuk diolah. Informasi mengenai alamat alumni hanya dapat disajikan sampai batas tingkat provinsi saja, hal tersebut juga masih terkendala dengan kurang valid dan kurang akuratnya data tentang alamat yang diberikan. 
Padahal informasi mengenai alamat, baik alamat kantor maupun alamat rumah alumni saat ini sangat bermanfaat bagi kampus, khususnya untuk kepentingan pengembangan program studi. Data-data alamat lulusan yang seharusnya dapat langsung ditemukan didalam peta, sehingga akan lebih mudah jika akan dilaksanakan survey lebih lanjut mengenai alumni. Namun hal tersebut belum dapat dilaksanakan.

Penyebab tidak validnya informasi alamat yang diberikan dikarenakan alumni lebih memilih menuliskan alamat tempat kerja hanya dengan menuliskan nama tempat kerjanya saja, pernyataan ini didukung oleh data Tracer Study alumni Universitas Negeri Semarang pada tahun 2012. Ketika data alamat tempat kerja didapatkan dengan valid, penyajianya juga mengalami kesulitan ketika dilaporkan kepada pihak birokrasi Universitas, karena penyajian hanya dapat dilaksanakan dengan diagram batang dengan batas lokasi Provinsi tempat kerja.

Menurut [3], posisi tempat kerja, posisi kantor merupakan salah satu data geografis yang berupa titik (point). Titik dalam sebuah data geografis merupakan bagian dari sebuah peta. Peta merupakan penyajian grafis dari permukaan bumi dalam skala tertentu dan digambarkan pada bidang datar melalui sistem proyeksi peta. Point yang valid atau dalam penelitian ini alamat kerja yang valid adalah alamat yang dapat diproyeksikan kedalam sebuah peta, baik peta digital maupun peta cetak.

Berdasarkan uraian tersebut peneliti melakukan penelitian berupa pembuatan Rancang Bangun Sistem Informasi Tracer Study Alumni Universitas Negeri Semarang dengan aplikasi Digital Maps.

\section{METODOLOGI}

Metode penelitian yang digunakan adalah metode studi pustaka, yaitu melakukan kajian pustaka dari berbagai sumber yang berkaitan dengan permasalahan sehingga didapat suatu ide mengenai bahan dasar pengembangan upaya pemecahan masalah. Sedangkan metode pengembangan sistem yang digunakan adalah dengan menggunakan metode prototype [4].

\section{a. Pengumpulan kebutuhan}

Pada tahap ini didefinisikan format seluruh perangkat lunak, mengidentifikasikan semua kebutuhan dan garis besar sistem yang akan dibuat.

\section{b. Membangun prototyping}

Membangun prototyping dengan membuat perancangan sementara yang berfokus pada prototipe awal (misalnya dengan membuat input dan format output).

\section{c. Evaluasi prototyping}

Evaluasi ini dilakukan untuk meyakinkan apakah prototyping yang sudah dibangun sudah sesuai dengan kebutuhan awal sistem atau belum. Jika sudah sesuai, maka langkah selanjutnya akan diambil. Namun jika tidak, prototyping direvisi dengan mengulang langkah-langkah sebelumnya. 


\section{d. Mengkodekan sistem}

Dalam tahap ini prototyping yang sudah final diterjemahkan ke dalam bahasa pemrograman PHP.

\section{e. Menguji sistem}

Setelah sistem sudah menjadi suatu perangkat lunak yang siap pakai, kemudian dilakukan proses pengujian. Pengujian ini dilakukan dengan White Box, Black Box, Basis Path, pengujian arsitektur, dll.

\section{f. Evaluasi sistem}

Dilakukan evaluasi apakah perangkat lunak yang sudah jadi sudah sesuai dengan yang tujuan awal. Jika ya, maka proses akan dilanjutkan ke tahap selanjutnya, namun jika perangkat lunak yang sudah jadi tidak/belum sesuai dengan apa yang diharapkan, maka tahapan sebelumnya akan diulang.

\section{g. Menggunakan sistem}

Perangkat lunak yang telah diuji siap untuk digunakan.

\section{HASIL DAN PEMBAHASAN}

Tracer Study Alumni (TSA) adalah kegiatan survey untuk mendapatkan informasi dari alumni dengan menggunakan sistem Questionnaire online, informasi yang diperoleh dari Questionnaire online adalah seputar karakteristik dan sosiologi sebelum kuliah, kegiatan pendidikan dan pembelajaran di kampus, transisi kedunia kerja, pekerjaan dan kompetensi hubungan pekerjaan dengan program studi. Setelah informasi atau data diperoleh, selanjutnya data akan diolah tim olah data.

Kegiatan pengolahan data TSA masih dilakukan dengan menggunakan metode manual yang membutuhkan waktu lama. Data yang diperoleh juga sering kali mengalami kesulitan untuk diolah. Informasi mengenai alamat alumni hanya dapat disajikan sampai batas tingkat provinsi saja, hal tersebut juga masih terkendala dengan kurang valid dan kurang akuratnya data tentang alamat yang diberikan. Padahal informasi mengenai alamat, baik alamat kantor maupun alamat rumah alumni saat ini sangat bermanfaat bagi kampus, khususnya untuk kepentingan pengembangan program studi. Data-data alamat lulusan yang seharusnya dapat langsung ditemukan didalam peta, sehingga akan lebih mudah jika akan dilaksanakan survey lebih lanjut mengenai alumni. Namun hal tersebut belum dapat dilaksanakan.

Penyebab tidak validnya informasi alamat yang diberikan dikarenakan alumni lebih memilih menuliskan alamat tempat kerja hanya dengan menuliskan nama tempat kerjanya saja, pernyataan ini didukung oleh data Tracer Study alumni Universitas Negeri Semarang pada tahun 2012. Ketika data alamat tempat kerja didapatkan dengan valid, penyajianya juga mengalami kesulitan ketika dilaporkan kepada pihak birokrasi Universitas, karena penyajian hanya dapat dilaksanakan dengan diagram batang dengan batas lokasi Provinsi tempat kerja.

Menurut [3], posisi tempat kerja, posisi kantor merupakan salah satu data geografis yang berupa titik (point). Titik dalam sebuah data geografis merupakan bagian dari 
sebuah peta. Peta merupakan penyajian grafis dari permukaan bumi dalam skala tertentu dan digambarkan pada bidang datar melalui sistem proyeksi peta. Point yang valid atau dalam penelitian ini alamat kerja yang valid adalah alamat yang dapat diproyeksikan kedalam sebuah peta, baik peta digital maupun peta cetak.

Dalam pembangunan sistem Tracer Study alumni ini menggunakan metode pengembangan sistem prototype. Menurut [5], prototyping adalah proses pengembangan sistem secara literatif dimana kebutuhan pengguna dikonversi kesistem yang sedang berjalan secara kontinue diperbaiki dengan kerjasama antara analsis pengguna. Tahap awal proses prototype pada sistem informasi Tracer Study alumni ini adalah tahap analisis. Analisis permasalahan yang dalam penelitian ini adalah bagaimana mendapatkan informasi alamat kerja alumni secara valid dan mudah diolah.

Untuk menentukan ruang lingkup aplikasi yang dibangun diperlukan perencanaan basis data dan perencanaan logika sistem yang selanjutnya dijabarkan dalam bentuk Entity Relationalship Diagram (ERD). Desain ERD sistem informasi TSA Universitas Negeri Semarang dapat dilihat pada Gambar 1.

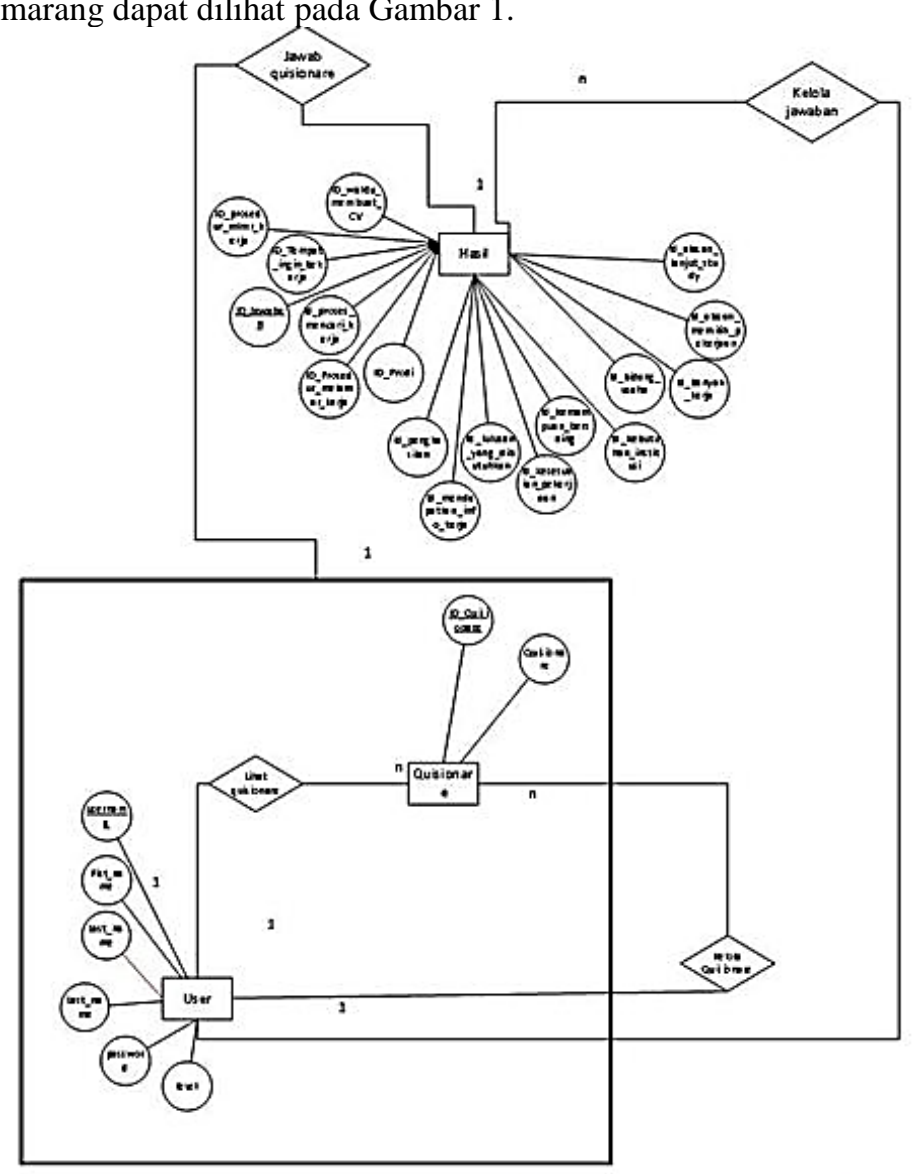

Gambar 1. ERD sistem informasi TSA UNNES dengan aplikasi Digital Maps 
Dari Gambar 1 dijelaskan bahwa pengguna dapat mengisi questionaire, mengolah questionaire, mengolah jawaban. Dari ERD daidapatkan jumlah tabel yang harus dibuat adalah sebanyak 22 tabel yang meliputi tabel account, tabel quistionaire, tabel hasil, tabel program studi, tabel prosedur melamar kerja, tabel alasan lanjut studi, tabel tempat ingin bekerja, tabel waktu prosedur melamar kerja, tabel waktu membuat $\mathrm{CV}$, tabel jenis bidang usaha, tabel mendapatkan info kerja, tabel kesesuaian pekerjaan, tabel penghasilan, tabel kebutuhan institusi, tabel banyak kerja, tabel proses mencari kerja, tabel kemampuan bersaing, tabel lulusan yang dibutuhkan, tabel provinsi, tabel kabupaten.

Perencanaan logika sistem dibangun dengan menggunakan Data Flow Diagram (DFD). Menurut [6], DFD adalah representasi grafik dari sebuah sistem. DFD terdiri dari 10 level, DFD level 0 dinamakan sebagai diagram konteks. Diagram konteks sistem informasi TSA universitas negeri semarang dapat dilihat pada Gambar 2.



Gambar 2. Diagram konteks sistem informasi TSA UNNES dangan aplikasi Digital Maps

Salah satu hal terpenting dari sebuah sistem informasi adalah desain antar muka pengguna dari sistem informasi. Tampilan utama dalam sistem informasi TSA universitas negeri semarang terdiri dari desain halaman home, desain halaman alumni, desain halaman enumerator dan desain halaman admin. 


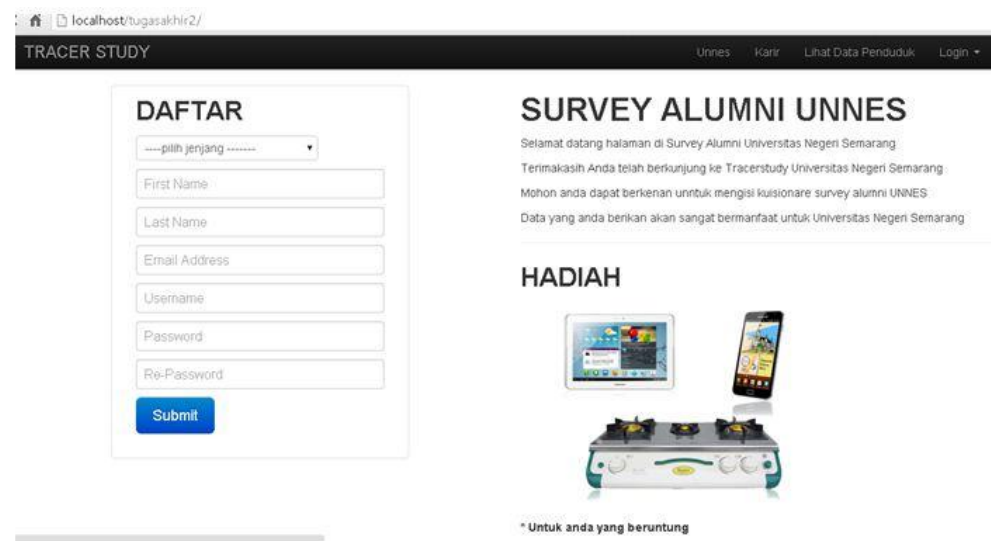

Gambar 3. Halaman awal sistem informasi TSA UNNES dengan aplikasi Digital Maps

Hasil pembuatan sistem informasi TSA Universitas Negeri Semarang dengan aplikasi Digital Maps dengan menggunakan struktur bahasa pemprograman PHP dan sistem basis data $M y S Q L$ serta media penyajian data menggunakan google maps API. Halaman awal sistem informasi ini ketika diakses seperti Gambar 3, berisi form pendaftaran bagi alumni yang belum memiliki akun di sistem ini, informasi umum mengenai penggunaan sistem ini, serta info hadiah yang diberikan dalam kegiatan TSA Universitas Negeri Semarang. Ketika pengguna berhasil login, maka pengguna akan dapat mengakses halaman questionaire seperti Gambar 4.



Gambar 4. Questionaire 
Tampilan menu hasil dari jawaban questionaire dapat dilihat pada Gambar 5.


Gambar 5. Menu hasil

\section{SIMPULAN}

Berdasarkan hasil dan pembahasan pada bab sebelumnya maka dapat disimpulkan bahwa rancang bangun sistem informasi TSA Universitas Negeri Semarang dengan aplikasi Digital Maps dibuat dengan menggunakan model pengembangan sistem prototype. Sistem informasi TSA Universitas Negeri Semarang berbasis Digital Maps dibuat dengan bahasa pemprograman $P H P$ dan $M y S Q L$ dengan menghubungkan pada koordinat lokasi di dalam google maps. Sedangkan pada implementasi rancang bangun sistem informasi TSA Universitas Negeri Semarang dengan aplikasi Digital Maps untuk pelacakan alumni dan pemetaan alumni berdasarkan lokasi pekerjaan.

\section{REFERENSI}

[1] Suharti, L dan Laksono F.P. 2012. Studi penelusuran (Tracer Study) terhadap Alumni Program Studi Manajemen Fakultas Ekonomika Bisnis Universitas Kristen Satya Wacana. Proceeding for Call Paper Pekan Ilmiah Dosen FEB Salatiga: Fakultas Ekonomika Bisnis Universitas Kristes Satya Wacana. Tersedia di

htt://prepository.library.uksw.edubitstreamhandle1234567891293PROS_Lieli\%2 0S-Ferrynela\%20PL_Studi\%20 Penelusuran\%20 (Tracer\%20Study) _Full\%20text.pdfsequence=5.pdf [ diakses13-03-2014].

[2] Milington, Claire. 2006. The Use of Tracer Studies for Enchancing Relevance and Marketability in online and Distance Education. Barbados Community Collage. Barbados. Tersedia di https3. amazonaws. comacademia. edu. documents4050245mzwandile_and_ocholla_prolissa_paper_revised_march_29libre.pdfAWSAccessKeyId=AKIAJ56TQJRTWSMTNPEA\&Expires=13953598 56\&Signature=zShg3uXK1mvcjkuJBbHMB9dLSaY\%3D. pdf. [diakses 21-032014].

[3] Riyanto. Putra, Prilnali Eka dan Inderlako dan Hendi. 2009. Pengembangan Aplikasi Sistem Informasi Geografis Berbasis Desktop dan Web. Yogyakarta: Gava Media. 
Zulfikar Adi Nugroho \& Riza Arifudin

[4] Ladjmudin dan Al-Bahra Bin. 2005. Analisis dan Desain Sistem Informasi. Yogyakarta: Graha Ilmu.

[5] Nugroho dan Adi. 2004. Konsep Pengembangan Sistem Basis data. Bandung: Informatika Bandung.

[6] Hidiyansyah dan Toni. 2010 Mengenal Konsep Diagram Alir Data. Yogyakarta: Andi. 